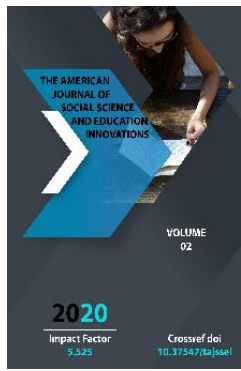

\title{
Alisher Navoi's Perspective on Music in His Works
}

\author{
Shokirhonov Bahtiyor \\ Lecturer Of Namangan State University, Uzbekistan
}

Journal Website:

http://usajournalshub.c

om/index,php/tajssei

Copyright: Original

content from this work

may be used under the

terms of the creative

commons attributes

4.0 licence.

\section{ABSTRACT}

This article reveals that Alisher Navoi, the king of gazal art, did not only write about poems, he also studied and gave a great amount of information on music, one of the most complicated form of art.

\section{KEYWORDS}

Alisher Navoi, composer, the science of music, Majolis un-nafois, musicians, Pahlavon Mahmud, theory of music, Mahbub ul-qulub, mutrib, muganni.

\section{INTRODUCTION}

"Majolis un-nafois" written by Alisher Navoi is a tazkira, an antology. It contains information about 459 works of contemporary poets, writers, scholars, musicians, singers and composers. The work consists of 8 parts, namely majlis. Each majlis is devoted to a particular group of creators [1, p.16]. In this work, Navoi classifies and demonstrates the level of music education, ethics and worldview of each person represented. At the same time, he expresses his positive and critical views on the work of cultural and artistic people. In the Tazkira, Navoi describes 16 people's work who worked in various fields of art. It should be considered that this is not just a description, but it is Navoi's own evaluation to the works of art representatives. In particular, their creative contribution to the science of music is also described. For example:

\section{MATERIALS AND METHODS}

Navoi evaluates the following 6 skillful musicians'performances in music seperately of his time: Mavlono Kadimi (a drummer); Muhammad Ali Garibi (a well-known musician of a number of musical instruments); Hoja Kamoliddin Udi (a musician and a delicate singer); Ustod Kulmuhammad Udi (a musician 
- the master of ud, gijjak, qobiz); composer Mir Habibulloh (ud musician); Moysungur Mirzo (a skillful musician);

Navoi states proudly that these 7 musicians were well-known and wrote books and manuscripts accordingly their reputation: Hoja Abdulvafoi Horazmi (wrote a musical manuscript, advor, a skilled musician), Mavlono Muhammad Jomi (another skilled musician with great knowledge on advor), Abdurahmon Jomi (musicologist - a specialist in music science), Mavlono Binoi (a musicologist who wrote a book about advor), Mavlono Shayhi (a musicologist), Pahlavon Muhammad Gushtigir (one of the most talented person on advor of his time), Hoja Abdulloh Sadr (a person of high knowledge in music and Advor, an unmatched musician on qonun instrument)

He also mentions about the following 3 composers: Mavlono Sohib Balhi (a composer, a musicologist on advor and other music types - the author of Chahorgoh melody); Hoja Yusuf Burhon (a preceptor of Navoi and many others with a great knowledge on music who composed Isfahon for his own couplets); Mavlono Solimi (a skilled musician of ud and tanbur who composed linked classifications). [2]

While evaluating the works of these musicians, musicologists and composers in his book, he especially mentions that they were singers and musicians who excelled in music practice and who were able to perceive music theory. He illustrated with the help of works of musicians that any person who know music theory and practice is able to create a melody accordingly to his knowledge.
Alisher Navoi's "Mahbub ul-qulub" (Love of Hearts) was written in 1500 and contains 3 parts with the first part including 40 fasl. [3]

Navoi gives definitions to some musical words of his time in the pages devoted to creators, gives his advatgeous and disadvantageous sides of their works and his positive and negative opinions of mutribs (people who were both singers and musicians) and mugannis. He places particular emphasis on the morals of the mutribs. When giving descriptions of them he says that there were both the ones who were able to influence on a person's spirit and the ones who were beggars, vagrants and obscene. This shows that there were two types of mutrins in the time of Navoi. He respected them as he considered them the people who positively affects on peopl. For example, he wrote: "Mutrib va mug'anniylar, ularning ikkalasiga dardu hol ahli jon qilurlar fido"deb ularga yuksak baho beradi" [4, p.6].

Alisher Navoi also gives definitons to some instruments in the first part 19th chapter of the book: flute - "gives way to heartache"; gijjak - "pleads with long tones"; tanbur "destroys with charm, tears please apart"; chang-"laments, Stretches its throat"; ud "its beggins is more plaintive than chang"; rubob_-"pleads bowing to the ground"; qonun _"is pleasant to listen to its tone"[5, p.30].

As Alisher Navoi describes his musical performances, he looks at each person's personality and behavior. He links the characteristics of each instrument with the human spirit and thoughts, and connects each instrument with the human world. In the work of Alisher Navoi's "Holoti Pahlavon Muhammad," we can encounter a great deal of information about the science of music. In 
this work, Alisher Navoi reveals the power of human strength, the prospects of aims through the talents, learning and striving for excellence in the life of a human being - the life of a friend. Navoi emphasizes the role of music in the attainment of human maturity, as in all life experiences and occupations. He covers composers' works based on the works of the then-heroine of his time, Pahlavan Muhammad.

Pahlavon Muhammad was one of the greatest figures and representatives of art of his time. Alisher Navoi considered this man to be his mentor, and they were close friends for 40 years. After Pahlavon Muhammad's death, Alisher Navoi wrote a booklet called "Holoti Pahlavon Muhammad" in honor of his memory.

The book emphasizes the work of Muhammad Pahlavan in the field of music. Pahlavon Muhammad explains through his works that music plays a vital role in humans' world of spirituality. Particularly, Navoiy wrote:

"Ul jumladin advor va musiqiy ilmidurkim, chun lahjasi va husni savti xo'b ekandur va usuli mazbut va harakoti va sakanoti marg'ub. UI daqiq fanda ko'shish va sa'y ko'rguzub, daxli tom va mahorati molokalom topib erdi va dilkash naqshlar va amallar va dilpisand qavllar va g'azallar tasnif qilur erdi va xo'b aytur erdi. Andoqki, eshitgan xavos va avom xushhol bo'Imoqda beixtiyor va o'rganmoqda beqaror erdilar" [6,p.111].

That is to say, Navoi considered Pahlavon Muhammad as a person who have particular knowledge on music wih skilfull performances, effective in composing, knowledgeable as a musicologist in various fields of music. He emphasizes that Pahlavon
Muhammad was advanced in the science of advor, his perception of methodology and efforts for it were effective.

He describes the outstanding efforts of Pahlavan Muhammad in the field of composership and singing. For instance, he reveals his compositional skills in a sentence: "Dilkash naqshlar va amallar va dilpisand qavllar..."

There is information in the description A description of Pahlavon Muhammad's composership: "Mashhur amallaridan biri "chahorgoh" amalidur..." - With this, Navoi confirms that one of the most striking examples of Pahlavan Muhammad's compositional work is his work "Chahorgoh" or "Chorgoh".

At the same time, Alisher Navoi in his book "Holoti Pahlavon Muhammad" provides information about teachers who have gained popularity in music, performance and creativity, saying that their work is a model for modern thinking and a model for education.

Our grandfather Navoi was a great performer not only in music itself, but also in the practice of music. Navoi performed skilfully in ud, rubab and qonun. Alisher Navoi did not overlook other types of art in the books he wrote throughout his life. His writings on music reveal that he was also a music expert. He himself played music on ud, qonun. Although he did not writie a book on music, many of his works contain information about music, art, music theory, knowledge of singers and musicians, and their performances.

\section{CONCLUSION}

We can assume from Navoi's "Majolis unnafois”, “Mahbub ul-qulub”, “Holoti Pahlavon 
Muhammad" that the art and culture in Temurids' era were in their high degree with talented, skilled and popular artists. According to "Majolis un-nafois", during that time there were many talented singers and musicians who left a rich musical heritage. "Mahbub ulqulub" provides information about singers and musicians who admires people with their charming melodies and the ones who make hearts distressed with their unpleasant songs. From these words of the him, the people of art should draw their own conclusions and follow the ethics of culture and art. Navoi's work "Holoti Pahlavon Muhammad" illustrates the role that music plays in the spiritual world in the example of his teacher and friend Muhammad. Navoi writes that Pahlavan is well-versed in the musical knowledge that had creations in various fields of music. As it can be seen, Navoi and many of his contemporaries acquired both theoretical and practical knowledge in music. By reading their works, we can gain not only the culture of the times, but also many theoretical knowledge.

\section{REFERENCES}

1. Soibjon Begmatov "The Work of Composers" Tashkent-2017. P-16.

2. Alisher Navoi. "Mukammal asarlar to'plami”. (20 volumes). Volume No.13. T., 1997.

3. https://uz.wikipedia.org/w/index.php?title =Mahbub_ul-qulub\&oldid $=2027616$

4. Alisher Navoi. "Mahbub ul-qulub".T., 1983.

5. A.Navoiy. "Holoti Pahlavon Muhammad". T., 2015

6. Ikromova. Gulhida. A. (2020). Developing the speech of primary school pupils through the folklore. ACADEMICIA: An
International Multidisciplinary Research Journal, 10(5), 567-571.

7. Muhamadjonovna, S. D. (2020). The development of sociolinguistic competence of future English language teachers through computer technologies. European Journal of Research and Reflection in Educational Sciences, 8 (3) Part II, 147-150.

8. Ярашова, Н. Ж. (2019). ПРОЯВЛЕНИЕ ИНТОНАЦИИ У ДЕТЕЙ ПОСРЕДСТВОМ ОБРАЩЕНИЯ. In ТРаДИциИ И НовациИ В профессиональной подготовке и деятельности педагога (рр. 128-130).

9. Jumaevna, Y. N. (2020). Occupation of the child's personal mental status in dialogual speech. Asian Journal of Multidimensional Research (AJMR), 9(5), 405-408.

10. Jumayevna, Y. N. (2019). Linguo culture logical features of metaphors in children's literature (On the example of khudayberdi tokhtabayev's creative work). ACADEMICIA: An International Multidisciplinary Research Journal, 9(4), 139-145. 